\title{
KINERJA PERALATAN MAGNETIK UNTUK MENINGKATKAN PERFORMANSI DAN MENGURANG EMISI GAS BUANG PADA MESIN OTTO EMPAT LANGKAH
}

\author{
Tulus Burhanuddin Sitorus ${ }^{1,2}$, Mulfi Hazwi ${ }^{1}$, Jaya Arjuna ${ }^{1}$ \\ ${ }^{1}$ Departemen Teknik Mesin Fakultas Teknik Universitas Sumatera Utara \\ ${ }^{2}$ PUI Energi Berkelanjutan dan Biomaterial USU \\ email: tburhanudin@yahoo.com
}

\begin{abstract}
National energy data note that Indonesia fossil energy potential consisting of petroleum, natural gas and coal can only last for 10 years, 31 years and 80 years from now if no new fossil energy reserves are found. It is necessary to save energy to anticipate these conditions. One of the efforts that have been done is saving the consumption of fuel oil that is used in the internal combustion engine. This research aims to increase the performance by reducing fuel consumption and exhaust emissions by using magnetic devices. The equipment of magnetic is placed on the intake manifold which is varied $10 \mathrm{~cm}, 20 \mathrm{~cm}$, and $30 \mathrm{~cm}$ from the combustion chamber to determine the effect of installing a magnetic field on the performance of the Otto engine. Gas emission analyzer is placed on the exhaust gas section. Besides that, there were also variations in engine speed consisting of $2000 \mathrm{rpm}, 2500$ rpm, $3000 \mathrm{rpm}, 3500 \mathrm{rpm}$, and $4000 \mathrm{rpm}$. Experimental data show that there is an increase in power and thermal efficiency and a decrease in specific fuel consumption when the engine uses magnetic devices ranging from $5.99-22.02 \%$. The exhaust gas emissions produced by Otto engine also decreased for CO and HC thereabouts 6-20\%.
\end{abstract}

Keywords: magnetic device, Otto engine, performance, exhaust gas emissions

\section{PENDAHULUAN}

Sumber energi yang paling banyak digunakan di seluruh dunia adalah energi fosil terutama bahan bakar minyak. Saat ini negara Indonesia masih sangat tergantung pada energi fosil. Hampir $95 \%$ dari kebutuhan energi Indonesia masih disuplai oleh energi fosil. Sekitar 50\% dari energi fosil tersebut adalah minyak bumi dan sisanya adalah gas dan batu bara [1]. Energi fosil adalah energi yang tak terbarukan dan akan habis pada beberapa tahun yang akan datang. Data dari rencana umum energi nasional tahun 2015-2050 menyatakan bahwa potensi energi fosil Indonesia yang meliputi minyak bumi, gas bumi serta batubara hanya dapat bertahan selama 10 tahun, 31 tahun dan 80 tahun dari sekarangi bila tidak ditemukan cadangan energi fosil yang baru [2]. Selain karena akan habis, energi fosil juga berdampak negatif terhadap lingkungan. Emisi gas rumah kaca dari pembakaran energi fosil berdampak pada pemanasan global yang menyebabkan perubahan iklim. Penyebab utama dari hal ini adalah ketidaksempurnaan pembakaran di ruang bakar, disamping itu juga kerugian gesekan yang ditimbulkan antar komponen mesin. Pembakaran yang tidak sempurna akan menimbulkan efek yang mengurangi kemampuan kerja mesin [3]. Selain itu juga pembakaran yang tidak sempurna mengakibatkan meningkatnya konsumsi bahan bakar dan emisi gas buang yang dihasilkan.

Berbagai cara peningkatan efisiensi atau penghematan bahan bakar untuk motor bakar telah dilakukan antara lain teknologi electronic fuel injection (EFI), penyempurnaan pembakaran seperti penggunaan twin spark plug, sistem pengaturan katup masuk bahan bakar dengan metode VVT-i dan VTEC serta peningkatan udara masuk dengan penambahan turbocarjer atau supercarjer. Salah satu metode untuk meningkatkan kinerja motor bakar yang dikembangkan saat ini adalah sistem magnetasi bahan bakar. Prinsip kerjanya adalah dengan melakukan magnetasi bahan bakar minyak yang mengalir dari pompa minyak menuju saluran bahan bakar (intake manifold) dengan menggunakan alat yang mengandung kekuatan magnet tertentu $[4,5]$. Sehingga sebelum dibakar di ruang bakar, bahan bakar tersebut sudah termagnetasi. Penelitian yang dilakukan di Laboratorium Energi Kobe University dengan menggunakan mesin diesel injeksi langsung tipe Yanmar NF-19SK menunjukkan penurunan 
konsumsi bahan bakar sebesar $13-14 \%$ pada kondisi beban normal saat menggunakan alat magnetasi [6].

\section{TINJAUAN PUSTAKA}

\subsection{Efek Magnetasi Pada Bahan Bakar Minyak}

Jika atom diletakkan dalam magnet yang seragam, elektron yang mengelilingi inti menjadi berputar. Perputaran ini menyebabkan medan magnet sekunder yang arahnya berlawanan dengan arah medan magnet yang diberikan. Pada bahan bakar minyak (BBM), saat BBM masih berada di tangki bahan bakar, molekul hidrokarbon yang merupakan penyusun utama BBM cenderung untuk saling tertarik satu sama lain, membentuk molekul-molekul yang berkelompok (clustering). Pengelompokan ini akan terus berlangsung, sehingga menyebabkan molekul-molekul hidrokarbon tidak saling terpisah atau tidak terdapat cukup waktu untuk saling berpisah pada saat bereaksi dengan oksigen di dalam ruang bakar [7]. Akibat buruk yang ditimbulkan adalah ketidaksempurnaan pembakaran yang dapat dibuktikan secara sederhana dengan ditemuinya kandungan HC pada gas buang. Adanya suatu medan magnet permanen yang cukup kuat pada molekul hidrokarbon yang bersifat diamagnetik akan menyebabkan reaksi penolakan antar molekul hidrokarbon sehingga terbentuk jarak yang optimal antar molekul hidrokarbon. Hal tersebut akan meningkatkan interaksi antar molekul hidrokarbon dengan oksigen. Partikel-partikel atom yang membentuk molekul hidrokarbon tersebut akan terpengaruh oleh medan magnet sehingga arahnya akan semakin sejajar atau terorientasi sesuai arah medan magnet [8].

Penggunaan magnet ditujukan untuk menghemat konsumsi bahan bakar melalui proses magnetasi seperti tampak pada gambar 1 [9]. Proses magnetasi diperlukan agar bahan bakar lebih mudah mengikat oksigen pada saat proses pembakaran dan mengurangi unburned hydrocarbon hasil proses pembakaran bahan bakar.

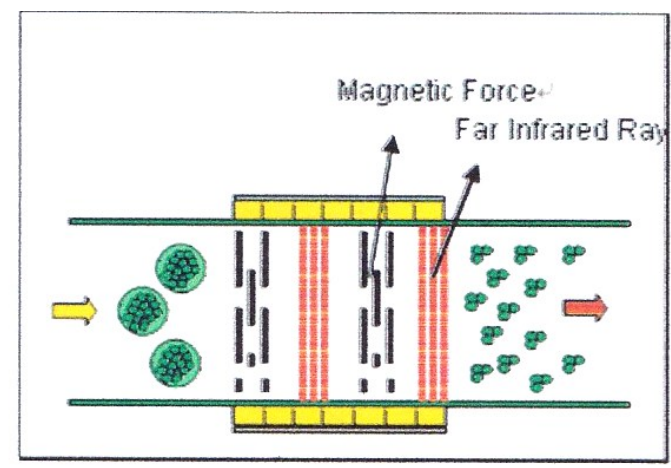

Gambar 1. Pengaruh magnetasi terhadap bahan bakar

Hal ini disebabkan ukuran struktur molekul bahan bakar akan berubah menjadi ikatan yang lebih kecil akibat magnetasi. Ukuran molekul yang lebih kecil ini secara langsung akan berakibat pada semakin mudahnya proses pembakaran dalam ruang bakar. Dengan kata lain proses magnetasi pada bahan bakar akan membuat pembakaran lebih sempurna [10]. Pada saat bahan bakar melalui selang, kekuatan magnetasi di dalam magnet yang ditempel di saluran bahan bakar menyebabkan terpecahnya ikatan karbon dalam bahan bakar menjadi bagian-bagian kecil ikatan ion. Ion positif akan tertarik oleh kutub negatif magnet sedangkan ion negatif akan tertarik oleh kutub positif magnet sehingga ion-ion positif dan ion negatif akan mengalir secara teratur setelah melewati medan magnet. Ikatan kecil dan beraturan inilah yang menyebabkan mudahnya oksigen bereaksi dengan bahan bakar pada proses pembakaran [11]. Efeknya bahan bakar akan lebih mudah terbakar di dalam ruang bakar sehingga mendorong terjadinya pembakaran sempurna.

\subsection{Parameter Motor Bakar}

Kinerja dari mesin Otto secara khusus ditunjukkan oleh nilai dari parameter-parameter mesin tersebut. Beberapa dari parameter tersebut dapat diuraikan seperti berikut [12]. Torsi merupakan parameter indikator yang cukup baik untuk mengetahui kemampuan mesin dalam melakukan suatu usaha. Torsi 
didefinisikan sebagai gaya yang bekerja pada jarak tertentu dimana nilai torsi suatu mesin dapat diperoleh dari hasil pengukuran dengan menggunakan alat torque meter.

Pada motor bakar umumnya dikenal ada dua jenis yaitu daya poros dan daya indikator. Daya tersebut dipengaruhi oleh putaran mesin dan torsi yang dihasilkan mesin. Namun yang digunakan dalam praktek di lapangan adalah daya poros. Daya poros atau daya efektif merupakan daya yang dihasilkan suatu mesin pada poros keluarannya atau biasa dikenal dengan brake horse power yang dihitung dengan persamaan :

$$
\dot{\mathrm{W}}=\frac{2 \pi \times \mathrm{N} \mathrm{x} \tau}{60000} \quad \mathrm{~kW}
$$

dimana $\mathrm{N}$ adalah putaran mesin (rpm) dan $\tau$ adalah torsi mesin $(\mathrm{Nm})$.

Konsumsi bahan bakar merupakan jumlah bahan bakar yang dikonsumsi persatuan unit daya yang dihasilkan per jam operasi. Secara tidak langsung konsumsi bahan bakar spesifik merupakan indikasi efisiensi mesin dalam menghasilkan daya dari pembakaran bahan bakar. Besarnya konsumsi bahan bakar spesifik dapat didefinisikan sebagai berikut:

$$
\mathrm{sfc}=\frac{\dot{\mathrm{m}}_{\mathrm{f}}}{\dot{\mathrm{W}}} \times 3600000 \quad \mathrm{gr} / \mathrm{kWh}
$$

dimana $\dot{m}_{\mathrm{f}}$ adalah laju aliran massa bahan bakar $(\mathrm{kg} / \mathrm{s})$.

Efisiensi termal suatu mesin didefenisikan sebagai rasio antara energi keluaran dengan energi kimia yang masuk yang dikandung bahan bakar dalam bentuk bahan bakar yang dihisap ke dalam ruang bakar. Efisiensi termal didefinisikan sebagai:

$$
\eta_{\mathrm{t}}=\frac{\dot{W}}{\dot{m}_{\mathrm{f}} \times Q_{\mathrm{HV}} \times \eta_{\mathrm{c}}}
$$

dimana $\mathrm{Q}_{\mathrm{HV}}$ adalah nilai kalor bahan bakar $(\mathrm{kJ} / \mathrm{kg})$ dan $\eta_{\mathrm{c}}$ adalah efisiensi pembakaran yang bernilai 0,97 .

\section{METODOLOGI PENELITIAN}

\subsection{Bahan}

Pengujian dilakukan dengan menggunakan bahan bakar pertalite. Peralatan pendukung yang ditambahkan ke saluran bahan bakar menuju ruang bakar adalah alat magnetik 2500 Gauss. Spesifikasi utama alat magnetik tersebut adalah model FT-15 produksi Indonesia, memiliki kekuatan magnet 2500 gauss dengan jarak antar kutub $0,75 \mathrm{~cm}$ dan dimensi $50 \mathrm{~mm}$ x $20 \mathrm{~mm}$. Untuk mengukur emisi gas buang digunakan alat uji emisi emission analyzer Sukyong SY-GA 401 dengan tingkat akurasi $\pm 97 \%$. Mesin uji yang digunakan adalah mesin Otto tipe empat langkah seperti tampak pada gambar 2 dengan spesifikasi utama mesin ditunjukkan oleh tabel 1.
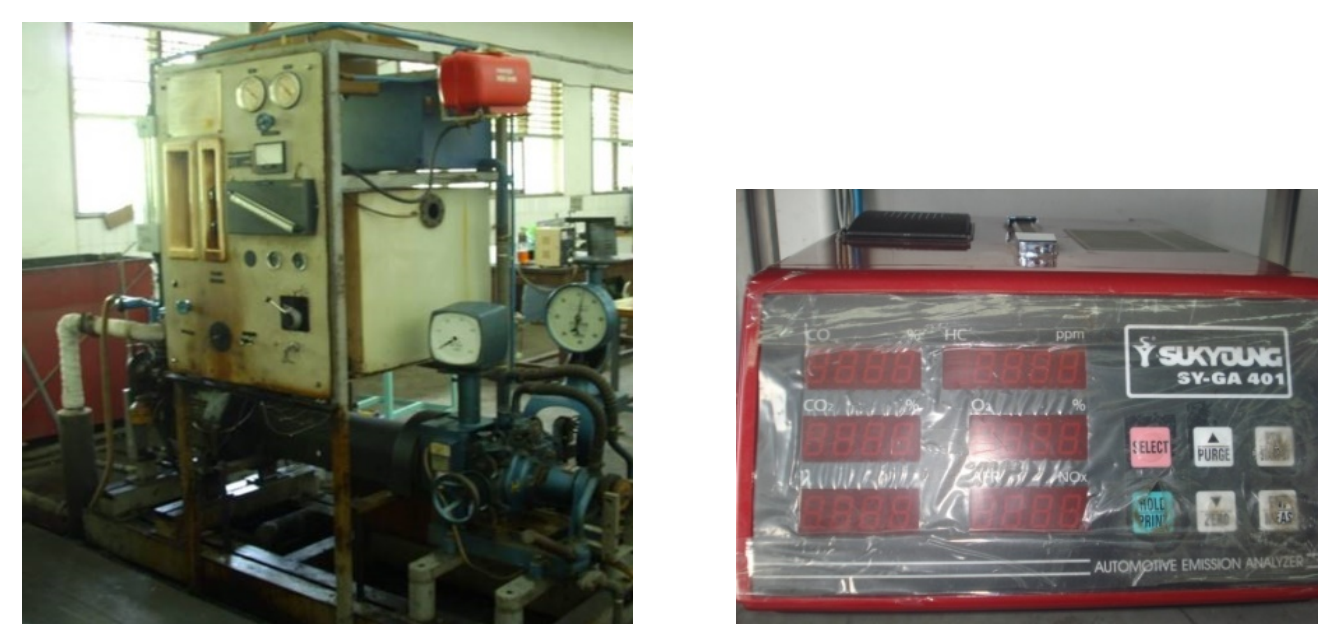
(a)

Gambar 2. a) mesin Otto 4 langkah b) alat uji emisi Sukyong SY-GA 401

Tabel 1. Spesifikasi utama mesin uji yang digunakan

Tipe mesin

Diameter x langkah

Jumlah silinder

Volume langkah

Perbandingan kompresi

Daya maksimum

Torsi maksimum
TecQuipment TD4A 024 / SOHC

$73 \mathrm{~mm} \quad x \quad 80,5 \mathrm{~mm}$

4

1486 CC

$10: 1$

$30 \mathrm{~kW} / 4900 \mathrm{rpm}$

$80 \mathrm{Nm} / 4500 \mathrm{rpm}$

\subsection{Skema Eksperimental}

Mesin Otto tipe empat langkah yang telah dikalibrasi dihubungkan dengan instrument alat ukur dan alat pendukung. Alat pendukung magnetik ditempatkan pada saluran bahan bakar (intake manifold) menuju ke ruang bakar yang divariasikan berjarak $10 \mathrm{~cm}, 20 \mathrm{~cm}$ dan $30 \mathrm{~cm}$ dari ruang bakar. Hal ini dilakukan untuk mengetahui efek dari pemasangan medan magnet terhadap kinerja mesin Otto terjadi. Alat ukur emisi gas buang ditempatkan pada bagian knalpot. Disamping itu dilakukan juga variasi putaran mesin yang terdiri dari $2000 \mathrm{rpm}, 2500 \mathrm{rpm}, 3000 \mathrm{rpm}, 3500 \mathrm{rpm}$ dan $4000 \mathrm{rpm}$. Instrumeninstrumen alat ukur tersebut dihubungkan pada sebuah data akuisisi dengan sistem komputer untuk dapat merekam semua perubahan kondisi yang terjadi seperti komposisi emisi gas buang yang dihasilkan, laju aliran bahan bakar, torsi yang dihasilkan mesin dan laju aliran udara yang dibutuhkan ke ruang bakar. Skema eksperimental dari penelitian yang dilakukan dapat dilihat pada gambar 3 .

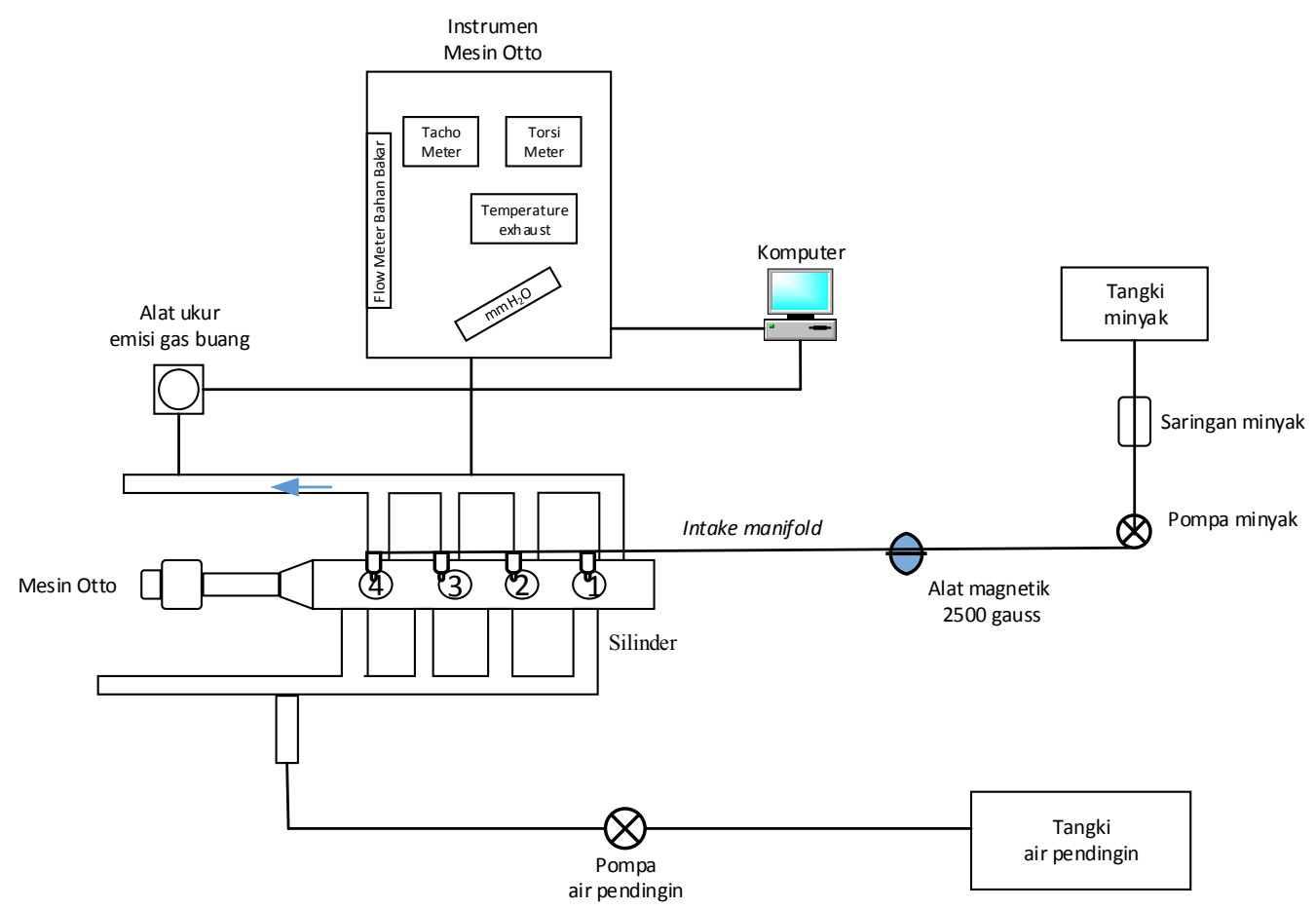

Gambar 3. Skema eksperimental

\section{HASIL DAN PEMBAHASAN \\ 4.1. Pengujian Kinerja Mesin}


Torsi maksimum diperoleh saat menggunakan alat magnetik 2500 gauss dengan jarak $30 \mathrm{~cm}$ sebesar $51,31 \mathrm{Nm}$ untuk putaran mesin $4000 \mathrm{rpm}$. Torsi minimum diperoleh 32,12 $\mathrm{Nm}$ dengan pengujian tanpa menggunakan alat magnetik pada putaran mesin $2000 \mathrm{rpm}$. Besarnya torsi rata-rata yang dihasilkan pada pengujian ini berkisar 41,34 Nm. Torsi yang dihasilkan saat mesin menggunakan alat magnetik dengan jarak $30 \mathrm{~cm}$ lebih besar disebabkan parameter torsi dipengaruhi oleh energi hasil pembakaran bahan bakar. Energi pembakaran yang dihasilkan semakin besar karena proses pembakaran menjadi lebih baik saat menggunakan alat magnetik.

Gambar 4 menampilkan perubahan torsi yang dihasilkan untuk setiap putaran mesin dengan dan tanpa menggunakan alat magnetik.

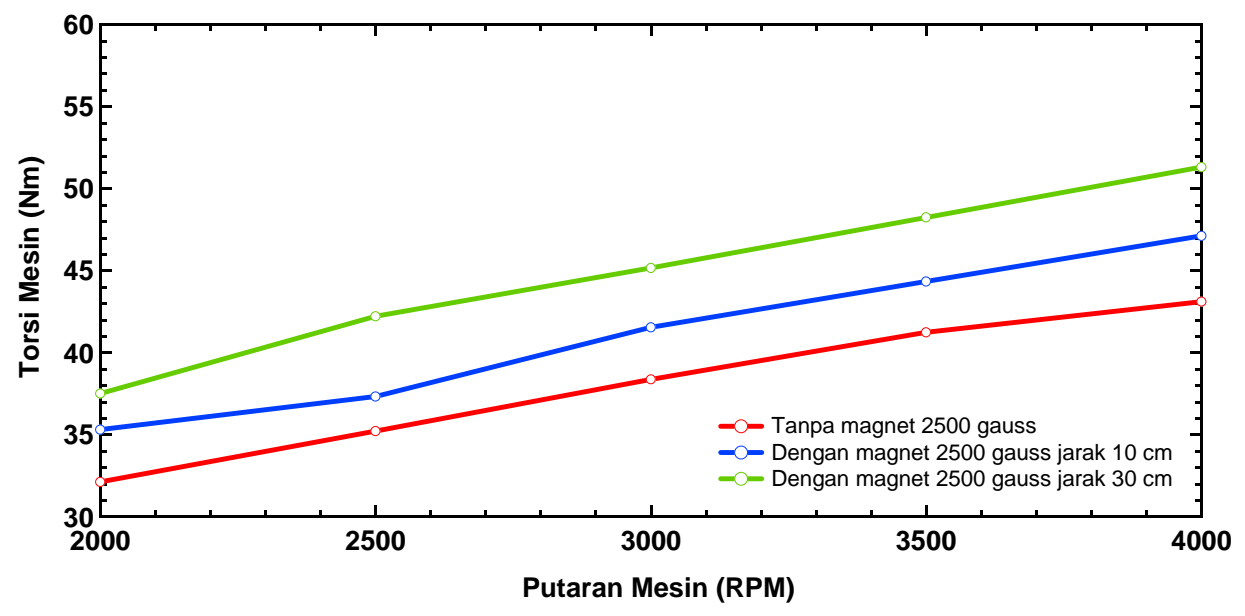

Gambar 4. Torsi mesin selama pengujian

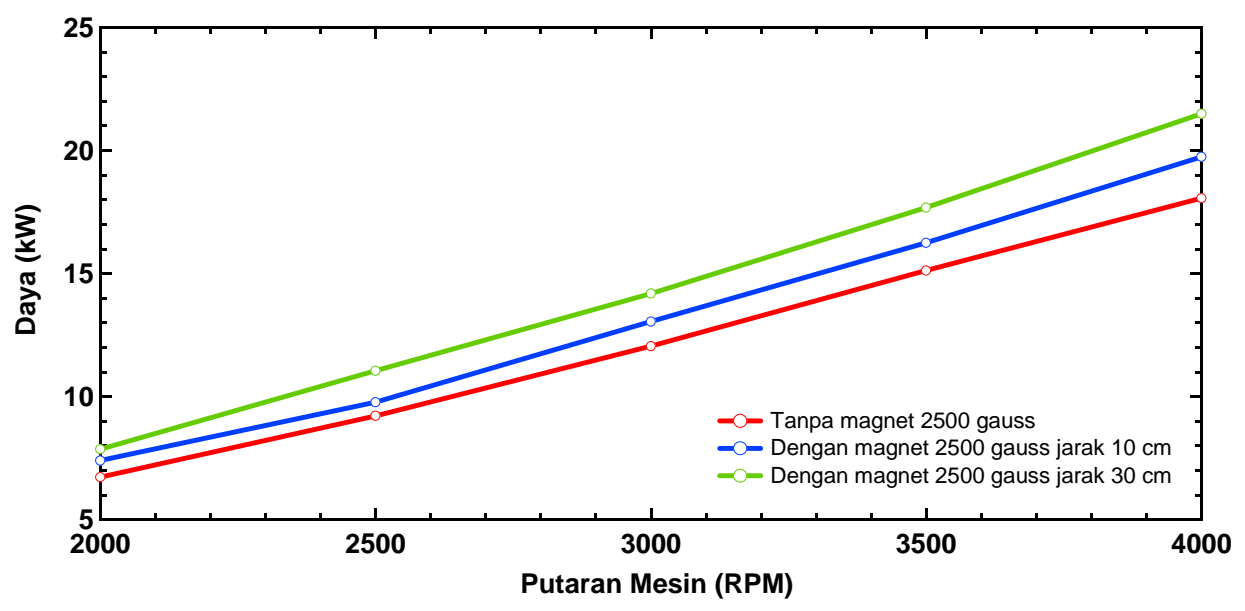

Gambar 5. Daya mesin selama pengujian 


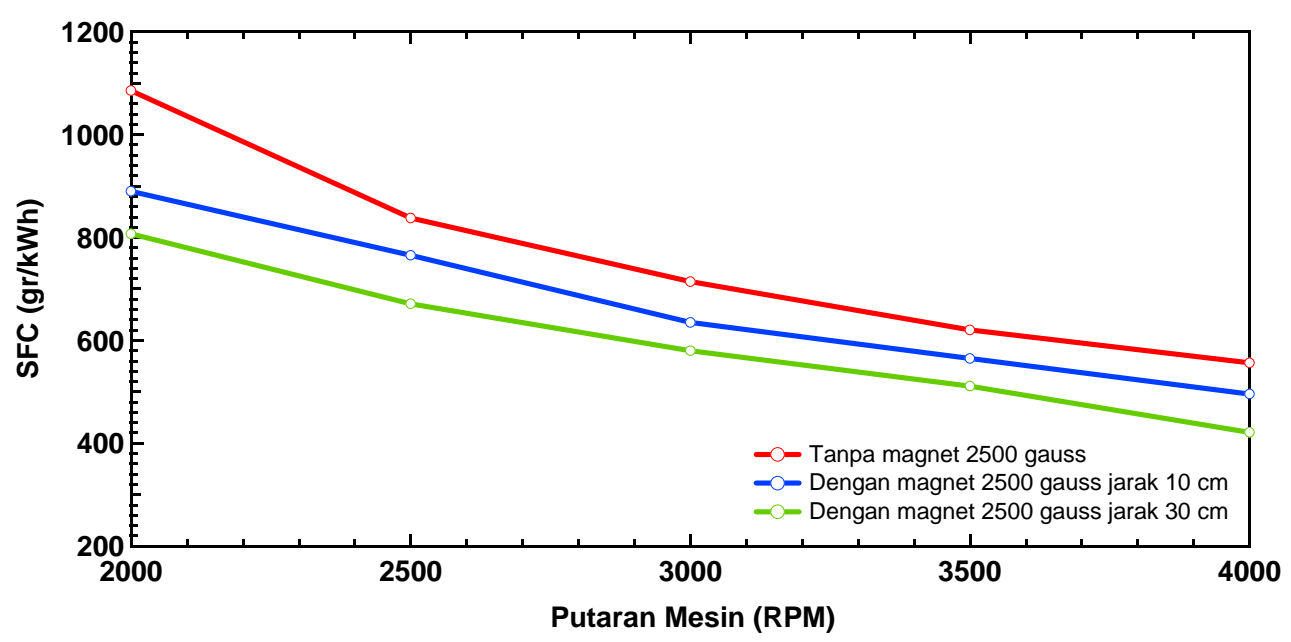

Gambar 6. Konsumsi bahan bakar spesifik selama pengujian

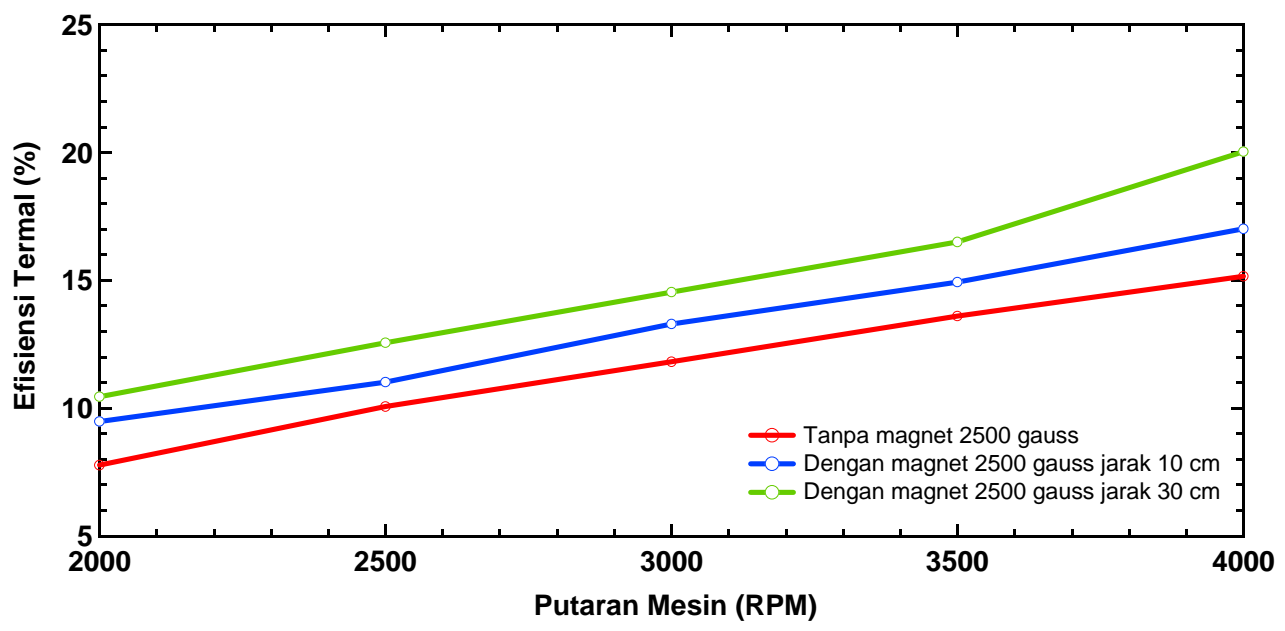

Gambar 7. Efisiensi termal selama pengujian

Gambar 5 menampilkan daya mesin yang dihasilkan selama pengujian. Berdasarkan data eksperimental diperoleh bahwa daya maksimum diperoleh sebesar 21,49 kW pada saat mesin beroperasi pada putaran mesin $4000 \mathrm{rpm}$ dengan menggunakan alat magnetik dengan jarak $30 \mathrm{~cm}$. Daya minimum diperoleh sebesar $6,73 \mathrm{~kW}$ saat tanpa menggunakan alat magnetik untuk putaran mesin $2000 \mathrm{rpm}$. Peningkatan daya poros saat mesin menggunakan alat magnetik berkisar 5,99$13,10 \%$. Parameter yang paling berpengaruh terhadap daya poros yang dihasilkan oleh mesin adalah torsi. Seperti diketahui bahwa bila torsi mesin semakin besar maka daya poros yang dihasilkan juga semakin besar dan begitu juga sebaliknya.

Gambar 6 menampilkan konsumsi bahan bakar spesifik yang dihasilkan mesin Otto selama pengujian dilakukan. Diperoleh nilai sfc maksimum sebesar 1085,58 gr/kWh saat mesin tanpa menggunakan alat magnetik untuk putaran mesin $2000 \mathrm{rpm}$. Nilai sfc minimum diperoleh sebesar 420,91 gr/kWh dengan putaran mesin $4000 \mathrm{rpm}$ saat mesin menggunakan alat magnetik dengan jarak $30 \mathrm{~cm}$. Konsumsi bahan bakar spesifik rata-rata yang dihasilkan dari pengujian yang dilakukan adalah $676,81 \mathrm{gr} / \mathrm{kWh}$. Penurunan konsumsi bahan bakar spesifik saat mesin menggunakan alat magnetik berkisar 8,62$18,05 \%$. Dapat dikatakan bahwa secara umum konsumsi bahan bakar spesifik saat mesin menggunakan alat magnetik mengalami penurunan. Salah satunya disebabkan proses pembakaran yang dihasilkan menjadi lebih baik saat mesin menggunakan alat magnetik. Hal ini membuat bahan bakar yang dibutuhkan menjadi lebih sedikit dibandingkan bila mesin dioperasikan tanpa menggunakan alat magnetik untuk kondisi pengujian yang sama. Gambar 7 menampilkan efisiensi 
termal yang diperoleh saat proses pengujian. Data eksperimental menunjukkan bahwa nilai efisiensi termal maksimum sebesar 20,03\% saat mesin menggunakan alat magnetik jarak $30 \mathrm{~cm}$ untuk putaran mesin $4000 \mathrm{rpm}$. Nilai efisiensi termal minimum diperoleh 7,77\% dengan putaran mesin $2000 \mathrm{rpm}$ saat mesin tanpa menggunakan alat magnetik. Besarnya nilai efisiensi termal rata-rata yang dihasilkan dari pengujian yang dilakukan adalah $13,21 \%$. Besarnya peningkatan efisiensi termal bila mesin otto menggunakan alat magnetik adalah berkisar 9,44-22,02\%. Parameter efisiensi termal dari motor bakar dipengaruhi oleh beberapa parameter seperti daya poros mesin, laju aliran bahan bakar ke ruang bakar dan nilai kalor bahan bakar yang digunakan.

\subsection{Komposisi Emisi Gas Buang}

Pada penelitian ini diukur kadar emisi gas buang yang dihasilkan oleh mesin uji dengan dan tanpa menggunakan alat magnetik.

Tabel 2 menampilkan kadar emisi gas buang yang dihasilkan dengan tiga jenis kondisi pengujian yaitu tanpa alat magnetik, dengan menggunakan alat magnetik jarak $10 \mathrm{~cm}$ dan $30 \mathrm{~cm}$.

Tabel 2. Data hasil pengukuran emisi gas buang

\begin{tabular}{lccccc}
\hline \multirow{2}{*}{ Kondisi } & $\begin{array}{c}\text { Putaran Mesin } \\
(\mathbf{r p m})\end{array}$ & $\mathbf{C O}_{\mathbf{2}}(\boldsymbol{\%})$ & $\mathbf{C O}(\boldsymbol{\%})$ & $\begin{array}{c}\text { HC } \\
(\mathbf{p p m})\end{array}$ & $\boldsymbol{O}_{\mathbf{2}}(\boldsymbol{\%})$ \\
\cline { 3 - 6 } & 2000 & 2.82 & 3.30 & 171 & 23.87 \\
& 2500 & 3.11 & 3.38 & 173 & 23.93 \\
Tanpa magnet & 3000 & 3.50 & 3.42 & 178 & 24.02 \\
& 3500 & 3.82 & 3.61 & 189 & 24.06 \\
& 4000 & 4.10 & 4.36 & 192 & 24.09 \\
\hline \multirow{3}{*}{ Dengan } & 2000 & 2.93 & 2.67 & 168 & 21.34 \\
magnet jarak & 2500 & 3.23 & 2.72 & 169 & 22.21 \\
$10 \mathrm{~cm}$ & 3000 & 3.65 & 2.70 & 167 & 23.05 \\
& 3500 & 3.95 & 2.80 & 169 & 21.43 \\
& 4000 & 4.25 & 2.95 & 171 & 21.47 \\
\hline \multirow{3}{*}{ Dengan } & 2000 & 2.95 & 2.69 & 165 & 23.34 \\
magnet jarak & 2500 & 3.32 & 2.83 & 170 & 22.21 \\
$30 \mathrm{~cm}$ & 3000 & 3.72 & 2.74 & 169 & 23.05 \\
& 3500 & 3.97 & 2.86 & 165 & 22.43 \\
& 4000 & 4.31 & 2.93 & 170 & 22.49 \\
\hline
\end{tabular}

Emisi gas buang yang diteliti meliputi kadar karbon dioksida $\left(\mathrm{CO}_{2}\right)$, karbon monoksida (CO), hidro karbon $(\mathrm{HC})$, dan oksigen $\left(\mathrm{O}_{2}\right)$ yang terdapat pada hasil pembakaran bahan bakar yang keluar dari knalpot dengan menggunakan alat ukur emisi Sukyong SY-GA 401. Seperti diketahui bahwa emisi karbon monoksida timbul karena pada saat proses pembakaran terjadi kekurangan oksigen. Kurangnya pasokan oksigen menyebabkan pembakaran menjadi tidak sempurna dimana atom $\mathrm{C}$ kekurangan $\mathrm{O}_{2}$ untuk membentuk $\mathrm{CO}_{2}$. Dari tabel 2 tampak bahwa tanpa menggunakan alat magnetik, mesin otto menghasilkan $\mathrm{CO}$ yang paling banyak untuk setiap variasi putaran mesin. Pengurangan emisi kadar $\mathrm{CO}$ terjadi saat mesin otto menggunakan alat magnetik yang berkisar 6-12\% bila dibandingkan tanpa menggunakan alat magnetik. Sedangkan untuk kadar emisi gas buang HC terjadi akibat kekurangan oksigen sehingga proses pembakaran berlangsung secara tidak sempurna karena banyak atom karbon yang tidak mendapatkan cukup oksigen sehingga membentuk gas HC. Dari hasil pembacaan alat ukur 
diperoleh kadar $\mathrm{HC}$ minimum saat mesin menggunakan alat magnetik dengan jarak $30 \mathrm{~cm}$. Kadar emisi HC maksimum diperoleh saat mesin tanpa menggunakan alat magnetik untuk setiap variasi putaran mesin. Pengurangan emisi kadar CO terjadi saat mesin Otto menggunakan alat magnetik yang berkisar $8-20 \%$.

\section{KESIMPULAN}

Pengujian terhadap mesin Otto tipe empat langkah dengan menggunakan alat pendukung magnetik 2500 gauss dengan menggunakan bahan bakar pertalite telah dilakukan. Hasil data eksperimental menunjukkan bahwa terjadi peningkatan daya, penurunan konsumsi bahan bakar spesifik dan peningkatan efisiensi termal berkisar 5,99-22,02\% saat mesin menggunakan alat magnetik. Hal ini disebabkan sifat magnetasi dari peralatan yang digunakan dapat memperbaiki kualitas bahan bakar yang masuk ke ruang bakar sehingga proses pembakaran yang terjadi di dalam ruang bakar menjadi lebih baik dibanding tanpa menggunakan alat magnetik. Untuk emisi gas buang yang dihasilkan maka terjadi penurunan kadar emisi CO dan HC berkisar 6 - 20\% selama menggunakan alat magnetik.

\section{UCAPAN TERIMA KASIH}

Penulis mengucapkan terimakasih kepada Universitas Sumatera Utara atas bantuan dana penelitian terapan TALENTA tahun anggaran 2018.

\section{DAFTAR PUSTAKA}

[1] J Arjuna et al 2018 IOP Conf. Ser.: Mater. Sci. Eng. 309012088

[2] Irvan et al 2017 IOP Conf. Ser.: Mater. Sci. Eng. 206012028.

[3] X.,P, Pham, D.Q. Vo, R.N. Jazar, "Development of fuel metering techniques for spark ignition engines", Fuel 206, 701-715, 2017.

[4] A. Yar, A. I. Bhatti, Q. Ahmed, "First principle based control oriented model of a gasoline engine including multi-cylinder dynamics", Control Engineering Practice 70, 63-76, 2018.

[5] C. Yao, Z. Dou, B. Wang, M. Liu, H. Lu, J. Feng, L. Feng, "Experimental study of the effect of heavy aromatics on the characteristics of combustion and ultrafine particle in DISI engine", Fuel 203, 290-297, 2017.

[6] G. Gonca, "Effects of engine design and operating parameters on the performance of a Spark Ignition (SI) engine with steam injection method (SIM)", Applied Mathematical Modelling, S0307-904X(17)30106-3, 2017.

[7] A. Hasanain, A. Wahhab, H. Hussain, A. Al-Kayiem, R. A. Aziz, M. S. Nasif, "Survey of invest fuel magnetization in developing internal combustion engine characteristics", Renewable and Sustainable Energy Reviews 79, 1392-1399, 2017.

[8] L. Liu, S. Chang, "Improvement of valve seating performance of engine's electromagnetic valvetrain", Mechatronics 21, 1234-1238, 2011.

[9] L.V. Polyacko, V.S. Morozova, V.S. Goun, "Environmental Performance Improvement in Gasoline Engines with External Mixture Formation", Procedia Engineering 150, 1156-1161, 2016.

[10] Y. Xu, H. Kang, J. Gong, S. Zhang, X. Li, "A study on the combustion strategy of gasoline/diesel dual-fuel engine", Fuel 225, 426-435, 2018.

[11] R. A. Kishore, S. Priya, "A review on design and performance of thermomagnetic devices", Renewable and Sustainable Energy Reviews 81, 33-44, 2018.

[12] F. Ariani et al 2017 IOP Conf. Ser.: Mater. Sci. Eng. 277012045. 